\title{
Use of Space Syntax through the map of segments for diagnostic integration and choice normalized in the City of Campina Grande - Brazil
}

\author{
Uso da sintaxe espacial através da análise de mapa de segmentos para diagnóstico integracional de \\ escolhas normalizadas na Cidade de Campina Grande - Brasil
}

Utilización del espacio Sintaxis aunque el mapa de segmentos para la integración de diagnóstico y

la elección normalizado en la Ciudad de Campina Grande - Brasil

\begin{abstract}
The article presents the profile of the city of Campina Grande, Brazil, from the perspective of the Space Syntax of the Theory of Social Logic of Space. In the methodology adopted, we used the model that starts from the Road Centre Line (RCL) map elaboration, which served as a basis for obtaining the Angular Segment Analysis, via Depthmapand QGIS software, generating the syntactic measures presented in the results. The objectives proposed in this study were achieved, for the results show that in the city there are spaces with organic and planned characteristics, which reflect socio-cultural aspects of occupation and settlement of the area along its predominantly heterogeneous formation. As for the urban form, there is a configuration composed of an integrating nucleus, located in the urban center; as for the scores presented, there are average values of NAIN (1.007), NACH (0.911) and INCH $(12,213)$ measures, in which $48 \%$ with $40 \%, 54 \%$ and $48 \%$, respectively, of the neighborhoods with average scores higher than the index presented by the city's configurational analysis. Most of the territory presents values above the average values for the city and for the Brazilian territory. Thus, it is concluded that the central regions seem to present, according to the data obtained, a more favorable configuration for mobility and accessibility, having in the peripheral neighborhoods segregationist aspects that can explain the restriction of movement of individuals regarding the access of goods and services in the city.
\end{abstract}

Keywords: Space syntax; Mobility; Accessibility; Urban planning.

\section{Resumo}

O artigo apresenta o perfil da cidade de Campina Grande, Brasil, sob a ótica da Sintaxe Espacial da Teoria da Lógica Social do Espaço. Na metodologia adotada, utilizou-se o modelo que parte da elaboração do mapa Road Center Line (RCL), que serviu de base para a obtenção da Análise do Segmento Angular, via software Depthmap e QGIS, gerando as medidas sintáticas apresentadas nos resultados. Os objetivos propostos neste estudo foram alcançados, pois os resultados mostram que na cidade existem espaços com características orgânicas e planejadas, que refletem aspectos socioculturais de ocupação e ocupação da área ao longo de sua formação predominantemente heterogênea. Quanto à forma urbana, há uma configuração composta por um núcleo integrador, localizado no centro urbano; quanto aos escores apresentados, há valores médios das medidas NAIN (1,007), NACH $(0,911)$ e INCH $(12.213)$, em que 48\% com $40 \%, 54 \%$ e $48 \%$, respectivamente, dos bairros com pontuação média superior do que o índice apresentado pela análise configuracional da cidade. A maior parte do território apresenta valores acima da média da cidade e do território brasileiro. Assim, conclui-se que as regiões centrais parecem apresentar, de acordo com os dados obtidos, uma configuração mais favorável à mobilidade e acessibilidade, tendo nos bairros periféricos aspectos segregacionistas que podem explicar a restrição de movimento circular.

Palavras-chave: Sintaxe espacial; Mobilidade, Acessibilidade; Planejamento urbano.

\section{Resumen}

El artículo presenta el perfil de la ciudad de Campina Grande, Brasil, desde la perspectiva de la Sintaxis Espacial de la Teoría de la Lógica Social del Espacio. En la metodología adoptada, utilizamos el modelo que parte de la elaboración del mapa Road Center Line (RCL), que sirvió de base para la obtención del Análisis de Segmento Angular, vía el 
software Depthmapand QGIS, generando las medidas sintácticas presentadas en los resultados. Se lograron los objetivos propuestos en este estudio, pues los resultados muestran que en la ciudad existen espacios con características orgánicas y planificadas, que reflejan aspectos socioculturales de ocupación y asentamiento del área a lo largo de su formación predominantemente heterogénea. En cuanto a la forma urbana, existe una configuración compuesta por un núcleo integrador, ubicado en el centro urbano; En cuanto a los puntajes presentados, existen valores promedio de las medidas NAIN (1.007), NACH (0.911) e INCH (12.213), en las cuales el 48\% con 40\%, 54\% y 48\%, respectivamente, de los barrios con puntajes promedio más altos que el índice presentado por el análisis configuracional de la ciudad. La mayor parte del territorio presenta valores por encima de los valores medios para la ciudad y para el territorio brasileño. Así, se concluye que las regiones centrales parecen presentar, según los datos obtenidos, una configuración más favorable para la movilidad y accesibilidad, teniendo en los barrios periféricos aspectos segregacionistas que pueden explicar la restricción de movimiento de la ciudad.

Palabras clave: Sintaxis espacial; Movilidad; Accesibilidad; Planificación urbana.

\section{Introduction}

The recent trend of rapid urbanization makes it imperative to understand urban characteristics such as infrastructure, population distribution, jobs, and services that play a key role in urban housing and sustainability. There is currently a healthy debate about what constitutes an optimal structure in relation to habitability in cities, interpolating, for example, between mono- and polycentric organizations. Here, economic flows and aggregates generated from millions of users, included in large urban centers, are used to extract global Intraurban travel. Therefore, this allows us to classify cities and establish a connection between the organization of mobility and the main urban indicators.

When studying the urban structure of cities, it is important to identify the main factors that can be related to the improvement of local mobility. To achieve this objective, studies located in specific realities that point out quantifiable indicators in urban road space are necessary for the planning and management of sectors linked to the area. To this end, it is necessary that the urban configuration be more intelligible to enable the mobility of people, goods, and services within the territory.

Rapid urbanization has led more than half of the world's population to live in cities, making it crucial to understand urban characteristics such as infrastructure, facilities, population distribution, jobs and services that play a key role in health, urban habitability and sustainability. The recent availability of digital traits of Information and Communication Technologies has allowed the study of urban systems with unprecedented spatial-temporal resolution, giving rise to a highly interdisciplinary enterprise, vaguely called city science. Previous research indicates a connection between urban characteristics and spatial organization of the city, giving rise to a debate about the optimization of such structures related to habitability. It is argued that population growth, together with the congestion induced by the concentration of activity, takes cities from a monocentric to a polycentric configuration. While polycentricity is responsible for the number of distinct activity centers, urban expansion is related to spatial dispersion. Cities can be compact, with all centers in a single district, or scattered if centers are distant, although they usually exist in a continuum between these two boundaries.

Here, we use anonymous and aggregate flows of users who have chosen Historical Location to extract global intraurban travel patterns to quantify the organization of urban mobility. We started by extracting the hierarchical structure of access points in cities and developed a metric, the flow hierarchy, based on the interaction between access points. The metric allows us to classify cities based on their level of dynamic hierarchy and thus establish a connection with the main urban indicators. Specifically, we show that cities with a higher mobility hierarchy exhibit more population mix, extensive use of public transport, higher levels of locomotion capacity, lower per capita emissions of pollutants, and better health indicators. The flow hierarchy contains more information on urban resources than traditionally used metrics such as population density and urban sprawl. We conclude with a discussion of the implications of our findings, including possible policy guidelines related to urban planning.

Therefore, the objective of this article is to analyze, given the configurational profile of the urban space of Campina 
Grande, located in the Northeast region of Brazil, what is the road design in which the movement of people is increasing or restrictive in terms of mobility and accessibility. This study aims to analyze the urban configuration of the city of Campina Grande, Brazil, from the perspective of the Spatial Syntax, given the intrinsic characteristics, the underlying and latent patterns that can be identified as positive and negative points of this type of human settlement and that can subsidize the improvement of urban planning based on the Theory of Social Logic of Space.

The city object of the research is a regional pole and presents the second largest economy in the state of Paraíba, ranked among the 120 largest municipal economies in Brazil. The population is currently estimated at approximately 410,000 according to the Brazilian Institute of Geography and Statistics, which makes it an urban agglomeration of medium size. These characteristics justify the need for studies related to urban mobility, as they may represent a parameter for other locations with similar characteristics to develop comparative studies. Although the city is listed as a reference and technological pole, it is also a reference point for the development of the city.

The research process first started with a survey on the theoretical basis on the subject (2); then, once the possibility of adapting the method to the urban configuration of the city was proven, a survey of the data necessary to achieve the results was carried out, as described in the methodology adopted (3); the results obtained through the object studied were relevant and innovative as to the description of the urban profile existing in this type of human settlement (4); finally, the conclusions of the study (5) that point out the heterogeneous singularity of the form of occupation characterized by disparities ranging from the level of Optimal Integration and Choice to the presence of regions typified as segregated with considerable problems regarding mobility.

Table 1. Evolution of Studies on the Theory of Space Syntax.

\begin{tabular}{|c|c|c|}
\hline Authors & Works & Importance \\
\hline $\begin{array}{l}\text { HILLIER, B.; } \\
\text { LEAMAN, A.; } \\
\text { STANSALL, P.; } \\
\text { BEDFORD, M. }\end{array}$ & $\begin{array}{l}\text { Space syntax. Environment and planning B: } \\
\text { Planning and design (1976). }\end{array}$ & $\begin{array}{l}\text { First work using the term space syntax. Argues that the } \\
\text { spatial configuration could influence human behavior } \\
\text { patterns. }\end{array}$ \\
\hline $\begin{array}{l}\text { HILLIER, B.; } \\
\text { HANSON, J. }\end{array}$ & $\begin{array}{l}\text { The social logic of space. Cambridge: University } \\
\text { Press (1984). }\end{array}$ & $\begin{array}{l}\text { The book explains how patterns of organization and spatial } \\
\text { arrangement (syntax) can influence human behavior. }\end{array}$ \\
\hline KLARQVIST, B. & A space syntax glossary. NA, v. 6, n. 2, 1993. & Glossary of main concepts used in Spatial Syntax. \\
\hline $\begin{array}{l}\text { HILLIER, B.; PENN, } \\
\text { A.; HANSON, J.; } \\
\text { GRAJEWSKI, T.; \& } \\
\text { XU, J. }\end{array}$ & $\begin{array}{l}\text { Natural movement: or, configuration and } \\
\text { attraction in urban pedestrian } \\
\text { movement. Environment and Planning B: } \\
\text { planning and design (1993). }\end{array}$ & $\begin{array}{l}\text { The article presents the Theory of Natural Movement of } \\
\text { People. }\end{array}$ \\
\hline RATTI, C. & $\begin{array}{l}\text { Space syntax: some } \\
\text { inconsistencies. Environment and Planning B: } \\
\text { Planning and Design (2004). }\end{array}$ & $\begin{array}{l}\text { The author highlights problems related to axial } \\
\text { representation, and the non-consideration of other urban } \\
\text { characteristics such as height of buildings and land use in } \\
\text { the calculations of measurements. }\end{array}$ \\
\hline HILLIER, B. & $\begin{array}{l}\text { Space is the machine: a configurational theory of } \\
\text { architecture (2007). }\end{array}$ & $\begin{array}{l}\text { He goes deeper into the main concepts of Space Syntax } \\
\text { described in The Social Logic of Space. }\end{array}$ \\
\hline TURNER, A. & $\begin{array}{l}\text { From axial to road-centre lines: a new } \\
\text { representation for space syntax and a new model } \\
\text { of route choice for transport network } \\
\text { analysis. Environment and Planning B: Planning } \\
\text { and Design (2007). }\end{array}$ & $\begin{array}{l}\text { Propõe neste artigo a utilização de eixos viários (Road- } \\
\text { Centre Lines - RCL) para a representação do espaço. }\end{array}$ \\
\hline HILLIER, B. & $\begin{array}{l}\text { Using DepthMap for Urban Analysis: A Simple } \\
\text { Guide On What to Do Once You Have an } \\
\text { Analysable Map in The System (2008). }\end{array}$ & $\begin{array}{l}\text { Tutorial on Depthmap software, which performs } \\
\text { calculations and syntactic analysis. }\end{array}$ \\
\hline $\begin{array}{l}\text { HILLIER, B.; } \\
\text { TURNER, A.; YANG, }\end{array}$ & $\begin{array}{l}\text { Metric and topo-geometric properties of urban } \\
\text { street networks: some convergences, }\end{array}$ & $\begin{array}{l}\text { It exposes that the spatial structure of the city is composed } \\
\text { of a top level (foreground), formed by a continuous network }\end{array}$ \\
\hline
\end{tabular}




\begin{tabular}{|c|c|c|}
\hline T.; PARK, H.T. & $\begin{array}{l}\text { divergences, and new results. Journal of Space } \\
\text { Syntax (2010). }\end{array}$ & $\begin{array}{l}\text { of free spaces that connect the city as a whole; and a bottom } \\
\text { level (background), formed by a "patchwork quilt." }\end{array}$ \\
\hline $\begin{array}{l}\text { HILLIER, B.; YANG, } \\
\text { T.; TURNER, A. }\end{array}$ & $\begin{array}{l}\text { Normalising least angle choice in Depthmap-and } \\
\text { how it opens up new perspectives on the global } \\
\text { and local analysis of city space (2012). }\end{array}$ & $\begin{array}{l}\text { They propose the standardization of two of the main } \\
\text { measures of the Spatial Syntax in the Depthmap software: } \\
\text { Integration (Normalised Angular Integration - NAIN) and } \\
\text { Choice (Normalised Angular Choice - NACH). }\end{array}$ \\
\hline $\begin{array}{l}\text { DHANANI, A.; } \\
\text { VAUGHAN, L.S.; } \\
\text { ELLUL, C.; } \\
\text { GRIFFITHS, S.; }\end{array}$ & $\begin{array}{l}\text { From the axial line to the walked line: Evaluating } \\
\text { the utility of commercial and user-generated } \\
\text { street network datasets in space syntax analysis } \\
(2013) \text {. }\end{array}$ & $\begin{array}{l}\text { It brings an analysis of two road axis models (Road Centre } \\
\text { Lines - RCL), being one commercial (ITN) and one of the } \\
\text { voluntary OpenStreetMap (OSM) geographic database, } \\
\text { comparing them with a traditional axial map. }\end{array}$ \\
\hline $\begin{array}{l}\text { AL-SAYED, K.; } \\
\text { TURNER, A.; } \\
\text { HILLIER, B.; IIDA, S.; } \\
\text { PENN, A. }\end{array}$ & Space Syntax Methodology (2014). & $\begin{array}{l}\text { Book that addresses the main theoretical elements and } \\
\text { brings a series of tutorials on different models and syntactic } \\
\text { measurements. }\end{array}$ \\
\hline HILLIER, B. (2016) & $\begin{array}{l}\text { What are cities for? And how does this relate to } \\
\text { their spatial form? (2016) }\end{array}$ & $\begin{array}{l}\text { It explores the idea that the city has two grids: one that is } \\
\text { structured and serves the microeconomy; and the other } \\
\text { structured by socio-cultural factors that serves the } \\
\text { residence. Both linked by a widespread center pattern. }\end{array}$ \\
\hline $\begin{array}{l}\text { KOLOVOU, I; GIL, J.; } \\
\text { KARIMI, K.; LAW, S.; } \\
\text { VERSLUIS, L. }\end{array}$ & $\begin{array}{l}\text { Road centre line simplification principles for } \\
\text { angular segment analysis (2017). }\end{array}$ & $\begin{array}{l}\text { It presents a proposal for simplifying geometries for road } \\
\text { axis maps (road centre lines - RCL), to improve the results } \\
\text { of the measurements in the Angular Segment Analysis. }\end{array}$ \\
\hline
\end{tabular}

Source: Adapted from Castro (2018).

\subsection{Angular Segment Analysis}

The Angular Segment Analysis divides the axial lines into segments and records the sum of the rotated angles from the initial segment to any other segment within the system. This angular sum is like the cost of a supposed trip through the graph, and from it, a shorter path (i.e., lower cost) can be calculated from one segment to another in the system. This process seeks the optimization of the logical sequence in the urban layout that has the lowest cost and the highest efficiency for a given trip. To apply this analysis as a graphical measure, the author proposed the use of the measure of 'intermediation' (or 'choice', as it is called in spatial syntax, Turner (2007).

In the measures applied through this methodology, the values are represented in a color palette, by convention, following a scale in which the warm colors (red and orange) indicate larger segments and therefore better accessibility; the cold colors (blue and green), on the contrary, indicate smaller segments, characteristic of irregular occupations devoid of urban planning.

In order to elaborate this type of map, it is first necessary to develop the Road-Centre Lines (RCL) map, provided by web mapping services with authorities (e.g. OS, Tiger, etc.) or volunteers (e.g. Osm) who are used to map the street network of cities, analyzing their properties and simulating patterns of urban activity, Dhanani et al., (2013).

Kolovou et al. (2017) demonstrated that angular segment analysis can be applied in RCL maps, which are more simplified and produce good correlation with vehicle motion data, and therefore can improve the accuracy of the analysis.

The original concept of Angular Segment Analysis was introduced by Hillier and Iida (2005) and later applied in UCL - Depthmap® (Turner, 2011). In order to carry out its angular measurement in the spatial configuration, it initially bases itself on the original axial map (Hillier; Hanson, 1984), which is divided into a segment map, defined as the street lines between the intersections.

The cost of the distance between two line segments of lower angular (geometric) change in a street network and of the criterion of road hierarchy is measured by "the sum of the angular changes that are made in a route, assigning a weight to each intersection proportional to the angle of incidence of two line segments at the intersection" (Hillier; Iida, 2005). The weight is defined so that the distance gain is 1 when the rotation is at a right angle or $90^{\circ}, 2$ if the angular rotation is $180^{\circ}$, and 0 if two 
segments remain straight. This notation can be described mathematically as (AL-SAYED, 2018):

$$
\omega(\theta) \alpha \theta(0 \leq \theta<\pi), \omega(0)=0, \omega\left(\frac{\pi}{2}\right)=1
$$

This angular cost can be applied as a weighting function to the centrality measures called Standard Angular Integration $A I N_{\theta}$ :

$$
A / N_{\theta}=i
$$

where $d_{\theta}$ is the length of the shortest path between the vertices $x$ and $i$.

The integration is pointed out as the main measure of Spatial Syntax and is based on the proximity centrality "closeness". It indicates the best way to go from one point to another in the city (to-movement potential) (Hillier, 2009). This facility is based on the set of segments that minimize the topological distance of change of direction to the other points of the city (Castro, 2016).

The intermediate $A C H_{B}$, or Choice, is calculated by generating shorter paths, with the lowest angular cost, among all the source and target segment pairs of the system. The flow through each segment is then added according to how many trips are made through each segment and divided by the total number of possible trips (Freeman, 1977 apud Turner, 2007), defined as follows:

$$
A C H_{B}=\frac{\sum_{i=1}^{n} \sum_{j=1}^{n} \sigma(i, x, j)}{\square} \text {, with } i \neq x \neq j
$$

where $\mathrm{s}(i, x, j)=1$ if the shortest path from $i$ to $j$ passes through $x$, and 0 otherwise.

For Castro (2016), the Choice is based on the crossing centrality "betweenness" when considering the possibility of crossing a specific segment from all other points of origin and destination.

To allow a better understanding of the syntactic properties of the measures between cities of different sizes, Hillier, Yang and Turner (2012) proposed the standardization of two of the main measures of the Space Syntax: the Integration (Normalized Angular Integration - NAIN) and the Choice (Normalized Angular Choice - NACH).

The two measures correspond to the two basic elements of any journey: selecting a destination from an origin (Integration) and choosing a route, and thus the spaces to be travelled between origin and destination (Choice).

$$
N A / N_{\theta}=\frac{(n+2)^{1.2}}{\square}
$$

The Normalized Angular Choice $\mathrm{NACH}_{B}$ is defined by:

$$
N A C H_{B}(x)=\log .
$$


where $(i, x, j)=1$ if the shortest path from $i$ to $j$ passes through $x$, and 0 otherwise.

Also known as the Spatial Accessibility measure, the INCH is an expression of the potential for human movement within urban space resulting from the combination of two measures of centrality, the Standard Integration (NAIN) and the Standardized Choice (NACH) (Hillier; Iida, 2005). The first one expresses the spaces that minimize distances; the second one, the crossing potential (Castro, 2016). The equation is expressed by:

$$
I N C H=\left(\frac{N D^{1.2}}{(T D+2)}\right) *\left(\frac{\log \log (C H)+1}{\log \log (T D+3)}\right)
$$

Equation (6)

where,

$\mathrm{ND}=$ Knot Counting.

$\mathrm{TD}=$ Total Depth .

$\mathrm{CH}=$ Measure of Choice.

For Hillier and Iida (2005), the INCH represents the potential of human movement in the urban space, being the junction of the main measures of spatial accessibility, as it aims to minimize the distances considering the crossing potential defined by the Choice.

The greater result of an integration tells us that at that point of the map there is a greater probability of movements and encounters with direct reflexes on accessibility and mobility. The Spatial Syntax reveals the social logic of the city (Holanda, 2002a).

Normally, as already described above, for the analysis of the results it is observed that the lines in red and orange are the most integrated, while the most segregated regions appear in blue and green. Lines (or segments) with Integration higher than 1.67 are very integrated and below 1, very segregated. As for the Choice values, above 1.4 are spaces with high potential of choice, and below 0.8, low potential of choice. (Hillier, Yang \& Turner, 2012).

\section{Methodology}

The research used the theoretical, methodological, and tooling apparatus developed from the studies of Hillier and Hanson (1984). They consider that space has a social logic that can inhibit or favor natural movement. Depending on the modeling of open (empty) and closed (full) spaces within the spatial configuration of urban design, some road networks have a greater number of crossings (nodes or connections) that allow a greater possibility of routes between pairs of origin and destination. Others of labyrinthine format present dependence on few roads that overload themselves to maintain the dynamics of movement in each space (Medeiros; Barros, 2014).

Initially, the RCL map for the studied settlement was prepared; posteriorly, this linear representation was the basis for the development of the segment map of the study object. Later these data generated in Depthmap ${ }^{\circledR}$ and their respective syntactic measurements were exported to the QGIS 2.14 software to develop the segment map and their respective measurements and maps - NAIN, NACH and INCH - for the city and neighborhoods.

To generate the result by neighborhoods, we used the segment map, .mif format files, and the shape of the neighborhoods of Campina Grande. Then, the input data was imported into a PostgreSQL database with the PostGIS extension enabled, through the QGIS 2.14 Database Manager. The average of the values of each indicator of the features (segments) fully contained within the limits of each neighborhood was calculated. For the discussion, the results were analyzed from the 
perspective of the diagnosis of the city and its neighborhoods through the variables representative of the model, and then the global data were compared with numbers presented.

The interpretation of mobility and accessibility in the research is based on the theoretical, methodological, and tooling aspects of the Theory of Social Logic of Space. According to the urban design and its different patterns - if more regulated, organic, fragmented, etc. - it is possible to assess whether the built space favors or hinders accessibility/mobility (MEDEIROS, 2013).

\section{Results and Discussion}

Campina Grande, as well as most Brazilian cities, showed a strong urban growth from the second half of the 20th century. The results of this process are a particular presence of urban voids, strong centrality, demographic dispersion, and the emergence of peripheral regions disintegrated from the socioeconomic dynamics of the city. It is important to make a brief description of the configuration of the urban form of the object studied, together with the configuration of the Spatial Syntax, since both can influence social relations and the dynamics of displacement in the territory.

The city emerged at the end of the 17th century through a settlement between the Piabas and Bodocongó streams, being the link between the hinterland and the coast of the State of Paraiba. In the 18th century, with churches, a street market, clay houses, masonary, and commerce, it was elevated to the category of "Vila Nova da Rainha".

With the arrival of the railroad at the beginning of the 20th century, development was driven by the local economy, influencing urban development, which became more intense in the 1970s. Below, it is possible to observe the evolution of the urban occupation process of the city, through three images, throughout the beginning and middle of the 20th century and more recently in the first decade of the 21st century. This expansion had a strong demographic increase in the 1970s and 1980s, in which the country experienced an expressive growth in urbanization resulting mainly from rural exodus.

Image 1. Map of Campina Grande in 1918, 1943 and 2006, respectively.
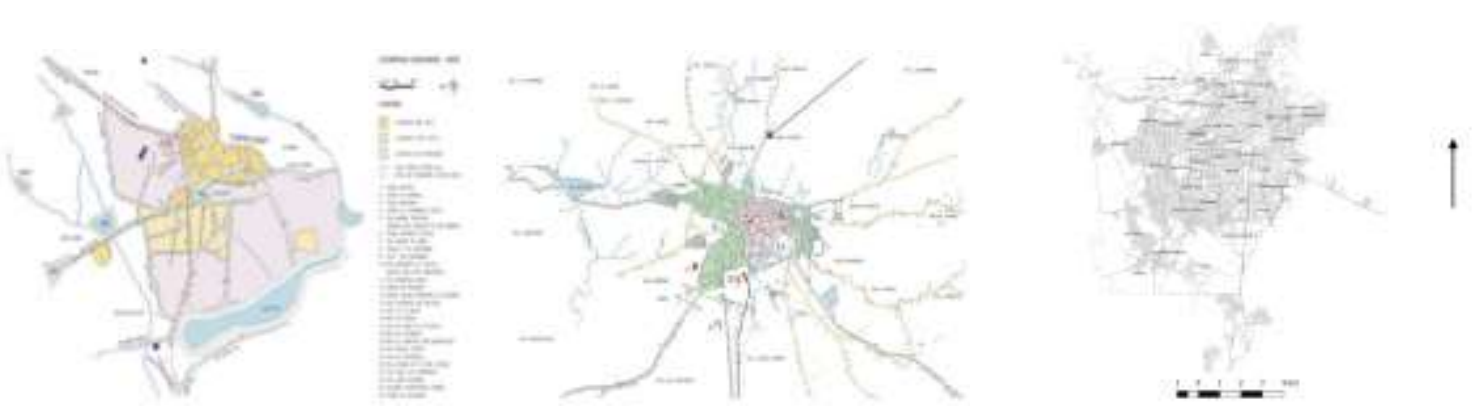

Source: Queiroz (2008) apud Barros Filho et al. (2012); Prefeitura Municipal de Campina Grande (2006).

The road network of the city of Campina Grande presents a limited number of accessible routes, as proven by the existence of few nodes and connections, characterizing a restrictive and labyrinthine design mainly in the most peripheral areas. In this sense, mobility is compromised by the excessive use of the few routes that present better accessibility for passersby, collapsing the road system at peak times.

The linear representation of the city of Campina Grande was obtained by braiding as few lines as possible that represented direct access in the urban space, through the cartographic base of the local road network. Then, with the aid of the Depthmap ${ }^{\circledR}$ tool (developed by University College London - UCL), a matrix of intersections was generated, in which the representative values of the segments were calculated. 
It is possible to identify aspects of regularity, like the chessboard, predominance of crossing in an " $\mathrm{X}$ " shape, and a proximity in their sizes and proportions. Examples are the districts of Prata, Centro, Lauritzen, São José, Quarenta, and Liberdade. This characteristic tends to strengthen the possibility of possible routes in the origin-destination pairs; therefore, these localities present higher spatial configuration values than the others, allowing optimal flow and movement relations.

Other neighborhoods seem to follow an adequacy of the mesh with the physical characteristics and socio-cultural patterns of occupation with absence of urban planning; this is the case for Cuités, Araxá, Novo Bodocongo, and Cidades. In these places, the existence of $\mathrm{T}$-shaped intersections and irregularities of the blocks in terms of shape and size is common, in addition to the predominance of the labyrinthine shape of the road network, reflecting low values of configurational indicators in the Spatial Syntax.

The rest of the neighborhoods that contemplate most of the city space present an intermediate configuration, however, much closer to the regularity presented by the superior indicators found. It is possible to find intersections both in the form of an "X" and a "T". The average numbers for the whole analyzed space present values that tend to a regularity, but without a clear definition of regularity.

The interactions between the variables indicate the effects of the Spatial Syntax in identifying the most integrated and connected (normalized) routes, which are more susceptible to trade and which, theoretically, should have greater accessibility to public transport, greater correspondence to the system, and, consequently, have greater attractions for the population.

Campina Grande has long roads that present a high degree of integration. Although it could be a good indication of an urban configuration focused on optimal mobility, they end up generating what scholars call "movement around", that is, a strong concentrating flow of movement in its surroundings. In the urban fabric they play the role of tentacles that connect the integrating nucleus to the most segregated settlements in the periphery, although they could play a role of denser urban agglomeration in their surroundings. It is possible that urban sprawl phenomena justify the presence of this phenomenon.

The work presents two approaches, macro and micro, regarding the reading of the representative indices of syntactic analysis in the urban fabric. First, we obtained a picture of the city and its paths; then, an analysis was made looking for the NAIN, NACH and INCH values by neighborhood.

Image 2. NAIN_, NACH_ and INCH_Campina Grande map, respectively.
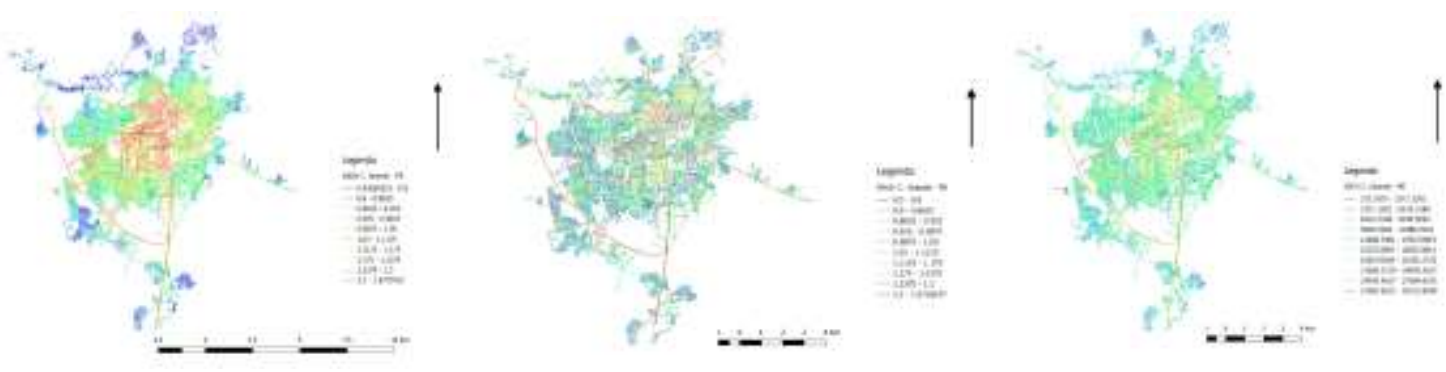

Source: Authors (2020).

By analyzing the NAIN_Campina Grande map, it was possible to locate some routes (lines/segments) that present greater integration in the road network. As for the NAIN result, the city presented a score of 1.007. In the set of descriptive measures about the city we have: Median 1.004 and Standard Deviation of 0.1954.

According to the color palette, the roads with red highlights are the most integrated. An analysis of the urban configuration shows that these roads have a value between 1.4638 and 1.578. In this case, the most integrated roads within this 
range are: Assis Chateaubriand Avenue, Marechal Floriano Peixoto Avenue, part of Gov. Antônio Mariz Highway, Prof. Almeida Barreto Avenue, Damasco Street, part of Almeida Barreto Av. and Siqueira Campos Street.

It was possible to elaborate a table and a representative map of NAIN_, $\mathrm{NACH}_{-}$and $\mathrm{INCH}_{-} \mathrm{Campina}$ Grande indexes by neighborhood. This analysis allowed classifying the set of neighborhoods within this methodology, presenting the following results in the form of a chart:

Image 5. Map of NAIN_, NACH_and INCH_Campina Grande by Neighborhoods.
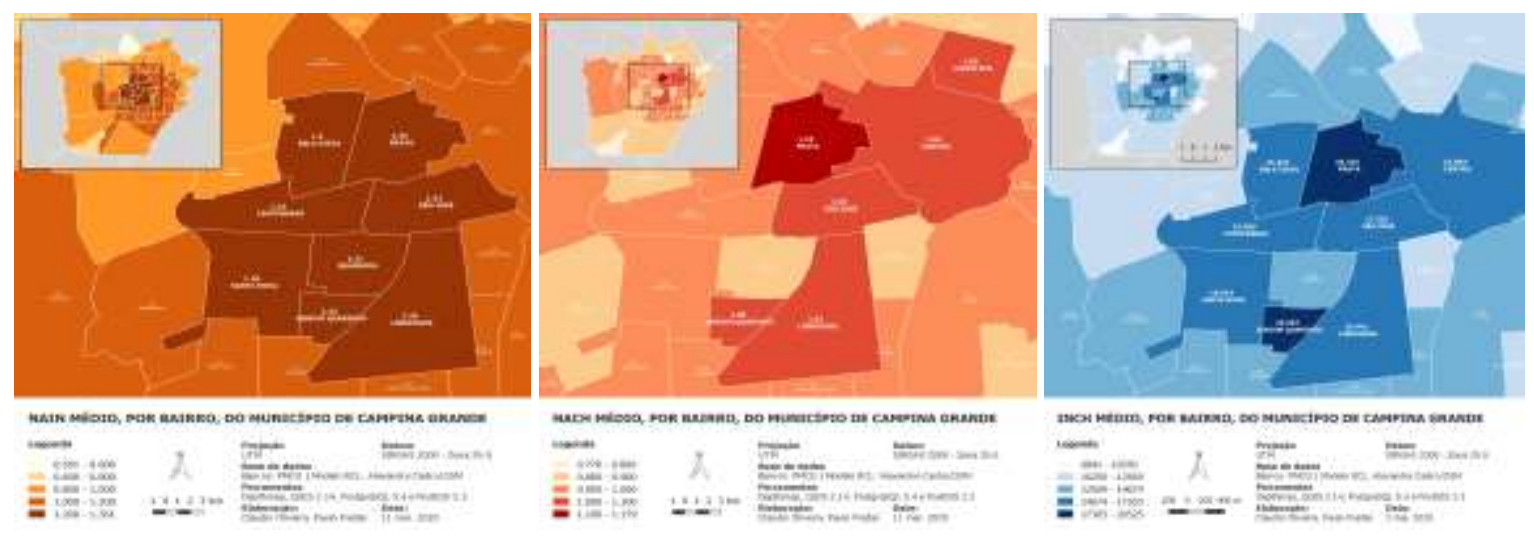

Source: Authors (2020).

Among the 50 districts of the city, 28 have an index above 1.0; contrarily, six districts have a value below the national average, being therefore more segregated: Jardim Continental (0.850), Nações (0.803), Cidades (0.797), Araxá (0.778), Novo Bodocongó (0.658) and Cuités (0.591). The ones with better integration are: Prata, São José, Jardim Quarenta, Santa Rosa, Liberdade, Centenário and Quarenta.

Through NACH, the topological steps are verified through the streets in red that present the best possibility of choice of accessibility for the pedestrian in the city and can consequently be an area of public services.

Regarding the analysis of the urban form of the city, the results found are an average NACH of 0.911. In the set of descriptive measures about the city we have: The Median 0.962 and the Standard Deviation of 0.3227 . In the analysis of the city, the routes that presented the segments with the highest index of Choice in the interval of 1.4146 and 1.5718, represented by a red color, were: Gov. Antônio Mariz Highway, Marechal Floriano Peixoto Avenue, part of Aprígio Veloso Street, Juscelino Kubitschek Avenue, Assis Chateaubriand Avenue, Plínio Lemos Street, Almirante Barroso Avenue, Almeida Barreto Avenue, Siqueira Campos Avenue, Francisco Nascimento Avenue, Damasco Street, Raimundo Nonato Street, and Manoel Tavares Street.

As for the analysis of best Choice by neighborhoods, 26 of these obtained an index equal to or higher than that obtained by the city (0.911), being the neighborhoods with a value above 1.0: Prata, Jardim Quarenta, Centro, Lauritzen, São José and Liberdade. When observing the localities that are below the value of the city, there are 19 neighborhoods: Jardim Tavares, Monte Santos, Dinamérica, Pres. Médici, Ramadinha, Sandra Cavalcante, Pedregal, Distrito Industrial, Acácio Figueiredo, Novo Bodocongó, Nova Brasília, Jardim Continental, Estação Velha, Cuités, Vila Cabral, Nações, Louzeiro, Cidades and Castelo Branco. 
Graph 1. Histogram of NAIN_, NACH_and INCH_Campina Grande by Neighborhoods.

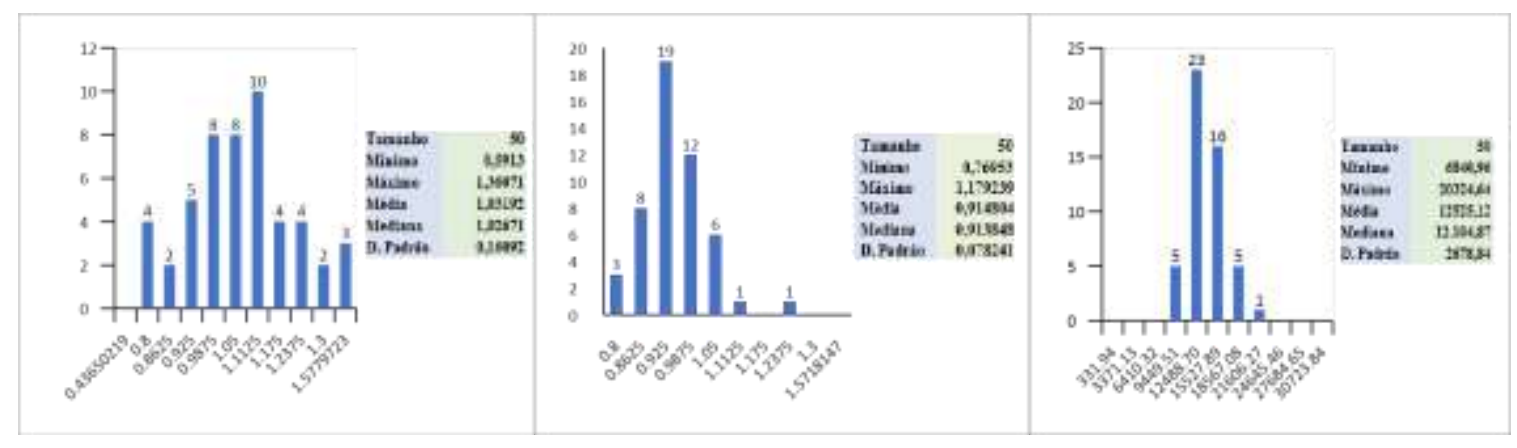

Source: Authors (2020).

Analysis of the smallest angle, as opposed to the smallest number of direction or topological changes. Integration (selection of a target) would be a measure of how accessible each segment is from all the others, or what potential it has as a target for movement. The Choice (selection of a route) evaluates how much each segment is used as a route with a smaller origin and destination angle in each area. Below are the results of the city and by neighborhoods, as to the junction of these two indexes, called INCH.

Although I have not found in the literature works that demonstrate a pattern of result for comparison, we can analyze the data from the result presented in this study: 12,204 average topological steps. In the set of descriptive measures about the city we have: Median 12,213 and Standard Deviation of 0.5495.

Based on the interval of 27,684 and 30,723, representative of the red color, therefore, the routes with better Choice and Integration are: Marechal Floriano Peixoto Avenue, Siqueira Campos Street, Assis Chateaubriand Avenue, and part of Gov. Antônio Mariz Highway.

In the analysis by neighborhoods, 21 localities have a higher value than the average of the city, being the neighborhoods with the best index: Prata, Jardim Quarenta, São José, Liberdade, Santa Rosa, Centro, Bela Vista and Centenário. The neighborhoods with the lowest index, below the value obtained by the city, total 28 , and of these, the ones that showed the lowest values are: Vila Cabral, Louzeiro, Araxá, Jardim Continental, Nações, Cidades, Novo Bodocongó and Cuités.

\section{Conclusion}

The use of the analysis model of the urban configuration proposed by the Spatial Syntax has proved adequate for the analysis of urban space in medium-sized Brazilian cities. The investigation of the attributes, having Campina Grande, Brazil, as a reference research object, indicated some important aspects, to mention: the integrating nucleus is represented by the urban center; $40 \%$ of the city presents a good Integration (NAIN); $54 \%$ presents a good Choice Index (NACH); and in the set of the previous values, represented by the INCH, $48 \%$ are above the values found in the average of the city.

Although the standard measurement presents itself as an optimal indicator for the context analyzed in this article, the average and maximum values may vary according to the size of the city (and consequently the number of axes or segments). However, the representative diagnosis of the analyzed space-time frame is highlighted here.

According to the radiocentric configurational design, since all roads lead to the center - presented in the results, it is possible to infer that peripheral neighborhoods present a more restrictive characteristic regarding the movement of people in the city. However, in the central regions, there is a more favorable standard for citizens' mobility and accessibility.

One of the aspects that should be considered regarding the study and that may interfere with the flow of vehicles and 
pedestrians, the following should be highlighted: although one road presents a good score of Integration and Choice, this characteristic may not necessarily be interesting for the city in terms of mobility and accessibility, as, first, there must be other parallel roads as route alternatives for pedestrians and cyclists, and second, there exists the feeling of belonging, the relationship that people have with the region where they live. This is the case of the citizen who lives in the border region between two neighborhoods and tends to identify with some other region and make use of another urban area that seems more convenient from a social and accessibility perspective.

In general, it can be considered that the heterogeneous patterns of formation and settlement in the city reflect the same logic of social inequality, because it is possible to identify spaces in neighborhoods around the central region that have high scores, while the other peripheral neighborhoods stand out for their segregationist profiles.

Although the study did not make a correlation with social variables, it is notorious, by empirical observation, that the best indices found reflect higher income occupations. It is noticeable that the logic of social disparity within the urban space reproduces the same prevailing socio-economic disproportion.

Faced with the need for sustainable development, cities that intend to be intelligent need to observe that not only is the use of technology an important variable for this objective, but also that the reversal of social reality pointed out by scientific studies indicates to public management what type of political intervention can be used to improve government actions.

\section{References}

Al-Sayed, k. et al. (2018) Space syntax methodology. (5th ed.). Bartlett School of Architecture, UCL.

Barros, A. P. B. G., \& Medeiros, V. S. (2014) Centralidades e sintaxe espacial: variáveis para a compreensão da acessibilidade urbana in KNEIB, Érika Cristiane (org.). Projeto e Cidade: centralidades e mobilidade urbana. UFG, Goiânia, 2014.

Barros Filho, M. et al. (2012) Tecidos Urbanos E Sistemas De Espaço Livres Em Campina Grande (Pb): Uma Descrição Da Qualidade Da Sua Forma Urbana. $7^{\circ}$ Colóquio Quapá-Sel. Campo Grande, 2012.

Dhanani, A., Vaughan, L. S., Ellul, C., \& Griffiths, S. (2013) The Axial Line to the Walked Line: Evaluating the Utility of Commercial and User-Generated Street Network Datasets in Space Syntax Analysis. in: Proceedings Of 8th International Space Syntax Symposium. Puc, Santiago, 11-32.

Hillier, B., Leaman, A., Stansall, P., \& Bedford, M. (1976) Space Syntax. Environment and Planning B: Planning and Design, $3(2)$, $147-185$.

Hillier, B., \& Hanson, J. (1984) The Social Logic of Space. University Press.

Hillier, B, et al. (1993) Natural Movement: Or, Configuration and Attraction in Urban Pedestrian Movement. Environment and Planning B: Planning and Design revue, 20(1), 29-66.

Hillier, B. E Lida, S. (2005) Network and Psychological Effects in Urban Movement. In: Spatial Information Theory. A.G Cohn E D. M. Mark (Comps.) 475490. [S.L.]: Springer-Verlag Berling Heidelberg.

Hillier, B. (2007) Space Is the Machine: A Configurational Theory of Architecture. London: Space Syntax.

Hillier, B., Turner, A., Yang, T., \& Park, H. T. (2010) Metric and Topo-Geometric Properties of Urban Street Networks: Some Convergences, Divergences and New Results. Journal of Space Syntax, 1(2), 258-279.

Hillier, B., Yang, T., \& Turner, A. (2012) Normalizing Least Angle Choice in Depthmap and how it opens Up New Perspectives on The Global And Local Analysis Of City Space. Journal of Space Syntax, 3(2), 155-193.

Hillier, B. (2016) What Are Cities For? And How Does This Relate to Their Spatial Form? -The Journal of Sapce Syntax. 6(2), 199 - 212.

Holanda, F. (2002) O Espaço De Exceção. Brasília: Editora Universidade De Brasília, 2002a. 466p. Uma ponte para a Urbanidade. R. B. Estudos Urbanos E Regionais, 5, 59-76.

Klarqvist, B. (1993) A Space Syntax Glossary. Na, 6(2).

Kolovou, I at al. (2017) Road Centre Line Simplification Principles For Angular Segment Analysis. In: Proceedings of 11th International Space Syntax Symposium. Instituto Superior Técnico, Portugal, 163.1-163.

Kneib, E. (Org.) (2014) Projeto E Cidade - Centralidades E Mobilidade Urbana. Universidade Federal De Goiás - Faculdade De Artes Visuais. curso de arquitetura e urbanismo. programa de pós-graduação projeto e cidade.

Medeiros, V. (2006) Urbis Brasiliae Ou Sobre Cidades Do Brasil: Inserindo Assentamentos Urbanos Do País Em Investigações Configuracionais Comparativas. Brasília: Ppg/Fau/Unb, 2006. 519 P.: Il. Tese (Doutorado) - Faculdade De Arquitetura E Urbanismo, Universidade De Brasília. 
Research, Society and Development, v. 10, n. 1, e54810111791, 2021

(CC BY 4.0) | ISSN 2525-3409 | DOI: http://dx.doi.org/10.33448/rsd-v10i1.11791

Medeiros, V. A. Z (2019) Base de dados Configuracional sobre Cidades Brasileiras. Brasília, Ppg/Fau/Unb.

Medeiros, V. (2013). Urbis Brasiliae: O Labirinto Das Cidades Brasileiras. Brasília: Editora Universidade De Brasília.

Oliveira, V. (2019) Diferentes Abordagens Em Morfologia Urbana. Contributos Luso-Brasileiros. Textos: Gobbi, Alessandra, Paio Et Alli. Urban Forms. (2a ed.).

Rocha, M. C. Da S., Soares De Medeiros, V. A. Configuração E Urbanidade Em Assentamentos Da Amazônia. Revista De Morfologia Urbana, 7(1), E00071.

Turner, A. (2007) From Axial to Road-Centre Lines: A New Representation for Space Syntax and A New Model of Route Choice for Transport Network Analysis. Environment and Planning B: Planning and Design, 34(3), 539-555. 